\title{
Paradigma Aktualisasi Diri Anak Sejak Di Usia Dini (Analisis Pada Penerapan Di Lingkungan Pendidikan Anak Dalam Perspektif Pendidikan Islam)
}

\author{
Ani Aryati \\ Universitas Muhammadiyah Palembang \\ aryatiani21@gmail.com
}

\begin{abstract}
Nature education is a responsibility shouldered the burden of someone, or a group on education due to something being performed, either because the concepts or ideas, words and deeds or because it doesn't do anything. Islamic education is actually very konprehensif in order to guarantee the outcome of a quality Islamic education because education in islam is not only in view of the realization of humanitarian responsibility but it is a religious responsibility. Islamic education is the embodiment of the top education family, society and the Government are synergistic. Responsibility of the respective responsibilities of the institutions of Islam could be financing, energy, materials, ideas, information, creation of a conducive educational, infrastructure and education. Each is involved in education should be mempertanggung with the dipikulnya the slightest burden either vertical (habl min Allah) or horizontally (habl min al-nas).
\end{abstract}

Keywords: Paradigm, Self Actualization, Children

\begin{abstract}
Abstrak: Hakekat tanggung jawab pendidikan adalah beban yang dipikul seseorang, atau kelompok mengenai pendidikan akibat sesuatu yang dilakukan, baik karena konsep atau gagasan-gagasan, perkataan dan perbuatannya ataupun karena tidak berbuat apa-apa. Pendidikan Islam sebenarnya sangat konprehensif guna menjamin hasil pendidikan Islam yang berkualitas karena pendidikan dalam dalam pandangan Islam bukan hanya realisasi dari tanggung jawab kemanusiaan tetapi merupakan tanggung jawab keagamaan. pendidikan Islam merupakan perwujudan atas pendidikan keluarga, masyarakat dan pemerintah secara sinergis. Perwujudan tanggung jawab masing-masing tanggung jawab lembaga pendidikan Islam dapat berupa pembiayaan, tenaga, bahan ajar, gagasan, informasi, penciptaan pendidikan yang kondusif, dan prasarana pendidikan. Setiap yang terlibat dalam pendidikan harus mempertanggung jawabkan beban yang
\end{abstract}

Belajea: Jurnal Pendidikan Islam Vol. 2, No 02, 2019;199-222 p-ISSN 2548-3390; e-ISSN 2548-3404, DOI:10.29240/belajea.v4i2.1050 available online at:http://journal.staincurup.ac.id/indek.php/belajea 
200 | Belajea: Jurnal Pendidikan Islam, Vol. 2, No. 02, 2019

dipikulnya sekecil apapun baik secara vertical (habl min Allah) maupun horizontal (habl min al-nas).

Kata Kunci: Paradigma, Aktualisasi Diri, Anak

\section{Pendahuluan}

Secara alamiah manusia tumbuh dan berkembang sejak dalam kandungan sampai meninggal, mengalami tahap demi tahap. Manusia mampu mencapai kesempurnaan/kematangan hidup melalui suatu proses. Pendidikan sebagai usaha membina dan mengembangkan pribadi manusia dari aspek-aspek rohani dan jasmani yang harus berkembang secara bertahap. Oleh karena suatu kematangan yang bertitik akhir pada optimalisasi perkembangan atau pertumbuhan, baru dapat di capai jika melalui suatu proses kearah tujuan akhir perkembangannya/pertubuhannya. Pendidikan Islam sebagai proses yang mengarahkan manusia kepada kehidupan yang baik dan mengangkat derajat kemanusiaan sesuai dengan kemampuan dasar (Fitrah).

Berbicara tentang pendidikan Islam, agaknya sangat idealis dan utopis dan bila hanya berkutat pada persoalan fundasional filosofis, karena kegiatan pendidikan sangat concern terhadap persoalan-persoalan operasional. Diantara kelemahan dari kajian pendidikan Islam yang selama ini tertulis dalam literatureliteratur kependidikan Islam adalah mereka kaya konsep fundasional atau kajian teoritis, tetapi miskin dimensi operasionalatau praktiknya. Atau sebaliknya kaya praktiknya/operasional, tetapi lepas dari fundasional atau dimensi teoritiknya ${ }^{1}$.

Cita-cita pendidikan Islam dalam membangun manusia diarahkan pada pendidikan keseimbangan antara antara rohani dan jasmani, mencakup dimensi yang luas, bersentuhan langsung dengan kawasan duniawi, merembes ke kehidupan akhirat. Pendidikan Islam tidak pernah menganakemaskan kepentingan duniawi dengan menganaktirikan kepentingan akhirat. Pendidikan

\footnotetext{
${ }^{1}$ Muhaimin, Paradikma Pendidikan Islam, (Bandung: Rosdakarya, 2003), h. v
} 
Islam lebih menekankan pada keseimbangan dan keserasian perkembangan hidup manusia untuk kepentingan di dunia dan akhirat ${ }^{2}$.

Maka warga pendidikan adalah penting dan tidak ada satupun yang terabaikan. Guru, murid, orang tua, pemerintah, anggota masyarakat dan apapun sebutannya, semua mempunyai peranan dalam mendidik kepribadian bangsa khususnya pembelajar yang sedang menuntut ilmu sekecil apapun. Pendidikan keluarga dalam Undang-Undang RI Nomor 20 Tahun 2003 tentang Sistem Pendidikan Nasional (Sisdiknas) disebut sebagi pendidikan informal. Dalam Pasal 27 disebutkan bahwa kegiatan pendidikan informal yang dilakukan keluarga dan lingkungan berbentuk kegiatan secara mandiri ${ }^{3}$.

Para ahli pendidikan Islam mencoba menfomulasikan hakekat pendidikan Islam, diantaranya: Ahmad D. Marimba: Pendidkan Islam Adalah bimbingan Jasmani, rohani berdasarkan hukum-hukum agama Islam menuju kepada terbentuknya kepribadian utama menurut ukuran-ukuran Islam. Sedangkan menurut Abdur Rahman Nahrawi :

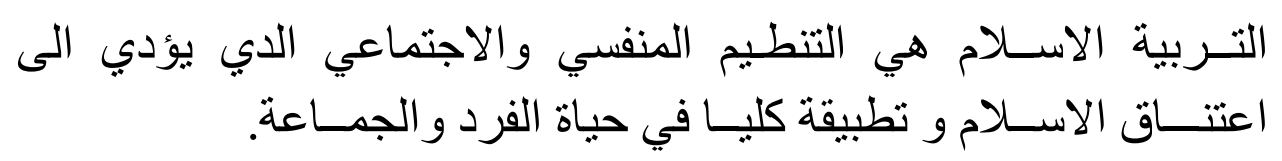

Pendidikan Islam ialah pengaturan pribadi dan masyarakat yang karenanya dapatlah memeluk Islam scara logis dan sesuai secara keseluruhan baik dalam kehidupan individu maupun kolektif.

Dari beberapa pendapat di atas para ahli ternyata berbeda pendapat dalam merumuskan Pendidikan Islam, Namun dari beberapa pendapat di atas dapat di tarik kesimpulan bahwa : Pendidikan Islam ialah bimbingan yang dilakukan oleh seorang dewasa kepada terdidik dalam masa pertumbuhan agar ia memiliki kepribadian muslim.

${ }^{2}$ Arifin, HM. Filsafat Pendidikan Islam. (Bumi Aksara. Jakarta, Cet V, 1996), h. 16

${ }^{3}$ Maragustam, Mencetak Pembelajaran Menjadi Insan Paripurna. Yogyakarta: Nuha litera, Cet. Pertama 2010), h. 118 
202 | Belajea: Jurnal Pendidikan Islam, Vol. 2, No. 02, 2019

Pandangan Immanuel Kant sama dengan tujuan pendidikan Islam, yakni melahirkan pribadi manusi yang sempurna, beragama, kreatif, produktif dan peka terhadap situasi lingkungannya. Akan tetapi realitas Pendidikan Islam saat ini bisa dibilang telah mengalami masa intellectual deadlock. Diantara indikasinya adalah; pertama, minimnya upaya pembaharuan, dan kalau toh ada kalah cepat dengan perubahan sosial, politik dan kemajuan iptek. Kedua, praktek pendidikan Islam sejauh ini masih memelihara warisan yang lama dan tidak banyak melakukan pemikiran kreatif, inovatif dan kritis terhadap isu-isu aktual. Ketiga, model pembelajaran pendidikan Islam terlalu menekankan pada pendekatan intelektualisme-verbalistik dan menegasikan pentingnya interaksi edukatif dan komunikasi humanistik antara guru-murid. Keempat, orientasi pendidikan Islam menitikberatkan pada pembentukan .abd atau hamba Allah dan tidak seimbang dengan pencapaian karakter manusia muslim sebagai khalifah fi al-ardl ${ }^{4}$.

Padahal, di sisi lain pendidikan Islam mengemban tugas penting, yakni bagaimana mengembangkan kualitas sumber daya manusia (sumber daya lahir batin) agar umat Islam dapat berperan aktif dan tetap survive di era globalisasi. Dalam konteks ini Indonesia sering mendapat kritik, karena dianggap masih tertinggal dalam melakukan pengembangan kualitas manusianya, baik secara produksi dan kepekaan sosial. Padahal dari segi kuantitas Indonesia memiliki sumber daya manusia melimpah yang mayoritas beragama Islam.

Pendidikan Islam telah merubah haluan, yang semula hendak melahirkan individu yang mulia lahir batin, ternyata direduksi hanya sebagai hamba Allah semata. Dalam membentuk pribadi yang sempurna tentu harus ada faktor pendukung yang ikut serta dalam mempengaruhi anak (anak didik) menjadi

${ }^{4}$ Abd. Rachman Assegaf, .Membangun Format Pendidikan Islam di Era Globalisasi., dalam Imam Machali dan Musthofa (Ed.), Pendidikan Islam dan Tantangan Globalisasi, (Yogyakarta: ArRuzz Media, 2004), Cet. I, h. 8-9 
pribadi shaleh, yaitu pribadi yang melakukan hubungan dengan yang transinden, sosial dan lingkungan. Maka faktor pendudukung yang tepat adalah keluarga, masyarakat dan sekolah.

\section{A. Penerapan di Lingkungan Keluarga}

Paling tidak ada tiga dimensi tanggungjawab yaitu: tanggungjawab pada pengembangan diri, tanggungjawab pada keluarga, dan tanggung jawab kepada masyarakat. Dimensi tanggung jawab kepada pengembangan diri masing-masing individu dan dimensi tanggung jawab kepada keluarga bardasar kepada firman Allah Swt:

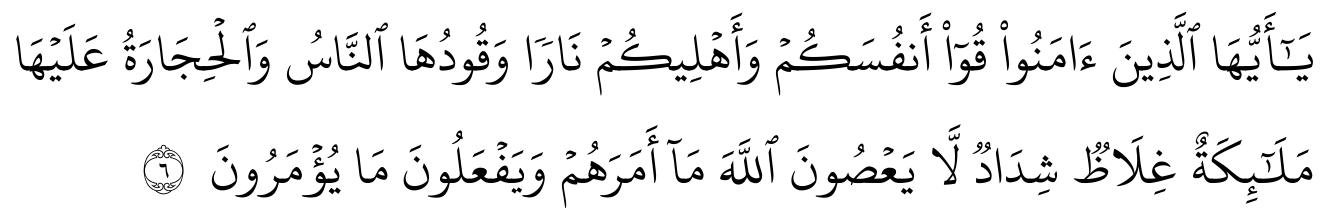

Hai orang-orang yang beriman, peliharalah dirimu dan keluargamu dari api neraka yang bahan bakarnya adalah manusia dan batu; penjaganya malaikat-malaikat yang kasar, keras, dan tidak mendurhakai Allah terhadap apa yang diperintahkan-Nya kepada mereka dan selalu mengerjakan apa yang diperintahkan. ${ }^{5}$

Dari ayat di atas dijelasanbahwa Allah memerintah bagi orang-orang yang beriman untuk menjaga dirinya sendiri dan keluarganya dari api neraka. Orang tua dan anak punya kewajiban untuk saling mengingatkan agar dapat berprilaku sesuai dengan syari'at dengan cara melaksanakan perintah-Nya dan menjauhi larangannya. ${ }^{6}$

Sedangkan tanggung jawab kepada masyarakat berdasar dalam al Qur'an:

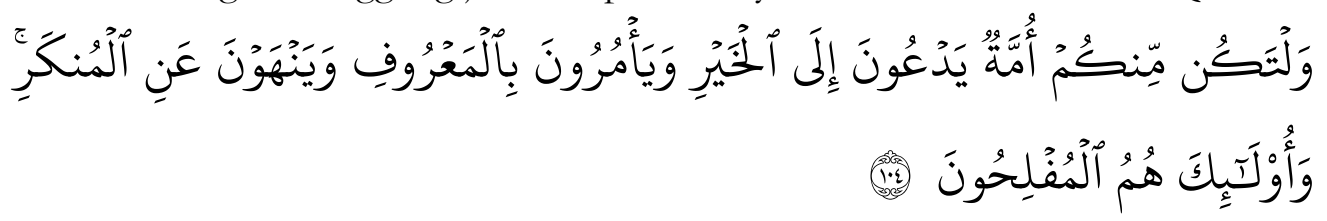

${ }^{5}$ QS. At-Tahrim [66]:6

${ }^{6}$ Eka Yanuarti, 'Pola Asuh Islami Orang Tua Dalam Mencegah Timbulnya Perilaku LGBT Sejak Usia Dini', Cendekia: Jurnal Kependidikan Dan Kemasyarakatan, 2019 <https://doi.org/10.21154/cendekia.v17i1.1337>. 
204 | Belajea: Jurnal Pendidikan Islam, Vol. 2, No. 02, 2019

Dan hendaklah ada di antara kamu segolongan umat yang menyeru kepada kebajikan, menyuruh kepada yang ma'ruf dan mencegah dari yang munkar merekalah orang-orang yang beruntung. ${ }^{7}$

Sejalan dengan pendapat di atas bahwa pendidikan sangat diperlukan manusia sebagai upaya untuk menemukan kemampuan ilmiah sebagai individu dan melatihnya supaya menjadi seorang warga negara yang baik, masyarakat dan harmonis, yang melaksanakan tugas-tugasnya secara efisien sebagai seseorang anggota masyarakat. ${ }^{8}$

Pendidikan dibutuhkan oleh individu-individu masyarakat sebab individuindividu yang baru lahir tidak dapat dipandang sebagai manusia sosial yang matang karena tidak mampu berkumpul dan menyesuaiakan diri didalam masyarakat. Pendidikan dapat membantu mengembangkan serta mendewasakan individu-individu dan mengaktualkan potensi-potensi mereka, persiapanpersiapan, serta memaksimalkan keahlian-keahlian. Pendidikan merupakan kebutuhan sosial dan kebutuhan individu?

Keluarga merupakan kelembagaan masyarakat yang memegang peranan kunci dalam proses pendidikan. Jadi ayah, ibu dan seluruh anggota keluarga adalah demikian penting dalam proses pembentukan dan pengembangan pribadi. Keluarga wajib berbuat sebagai ajang yang diperlukan sekolah dalam hal melanjutkan kematangan sosiologi kognitif. Demikian juga keluarga dapat berperan sebagai sarana pengembangan kawasan afektif dan psikomotor. Dalam keluarga diharapkan berlangsungnya pendidikan yang berfungsi pembentukan

${ }^{7}$ QS. Ali Imron[3]:104

8 Eka Yanuarti, 'Pendidikan Islam Dalam Perspektif Filsafat Idealisme', BELAJEA: Jurnal Pendidikean Islam, 2016 <https://doi.org/10.29240/BJPI.V1I2.108>.

${ }_{9}^{9}$ Maragustam, Mencetak Pembelajaran..., h. 120 
kepribadian sebagai makhluk individu, makhluk sosial, makhluk susila dan makhluk keagamaan ${ }^{10}$.

Pendidikan keluarga termasuk pendidikan informal dan bentuk kegiatannya ialah belajar secara mandiri. Dalam Islam tanggung jawab pendidikan bermula dari keluarga yakni ayah, kemudian ibu, dan anak-anaknya. Jika mereka mampu membentuk kepribadian anak sebagai makhluk individu terutama pada pengembangan faktor indogen yakni kemampuan-kemampuan atau potensi-potensi menjadi nyata, maka tanggung jawab pendidikan dibebankan kepada diluar keluarga seperti orang-orang yang mampu, pemerintah, dan lain sebagainya. Jika tidak demikian maka fungsi manusia sebagai kholifah dan hamba Tuhan tidak akan berjalan dengan baik.

Ada beberapa alasan kenapa pendidikan keluarga ini penting. Pertama, dasar-dasar kelakuan dan kebiasaan peserta didik tertanam sejak didalam keluarga, juga sikap hidup serta kebiasaan-kebiasaannya yang baik dakam keluarga ini akan menjadi karakter anak setelah ia menjadi dewasa. Kedua, anak menyerap adat istiadat dan prilaku kedua orang tuanya dengan cara bertaklid dengan cara meniru atau mengikuti dengan tidak tahu apa dasar, bukti dan alasannya, disertai ras puas. Ketiga dalam pendidikan keluarga berjalan secara natural, alami dan tidak dibuat-buat. Kehidupan penuh dengan keahlian, akan terlihat jelas sifat-sifat anak yang asli yang dapat diamati orang tua terus menerus dan karenanya orang tua dapat memberikan pendidikan yang sesuai dengan konteksnya dan sesuai dengan karakter anak-anaknya. Keempat, dalam pendidikan keluarga berlangsung dengan penuh cinta kasih dan keikhlasan. Orang tua tidak pernah terlintas dalam pikirannya tentang gaji dan penghargaan dalam mendidik anak-anaknya ${ }^{11}$. 130

${ }^{10}$ Imam Bernadib, Pemikiaran Tentang Pendidikan Baru. (Yogyakarta: Andi Offset. 1983), h. ${ }^{11}$ Maragustam, Mencetak Pembelajaran..., h. 124 
206 | Belajea: Jurnal Pendidikan Islam, Vol. 2, No. 02, 2019

Pada masyarakat yang masih sederhana, keluarga mempunyai dua fungsi; fungsi konsumsi dan fungsi produksi. Kedua fungsi ini mempunyai pengaruh yang sangat besar bagi anak. Kehidupan masa depan anak pada masyarakat tradisional tidak jauh berbeda dengan kehidupan orang tuannya. Pada masyarakat semacam ini, orang tua yang mengajar pengetahuan dan keterampilan yang diperlukan untuk hidup. Orang tua pula yang melatih dan memberi petunjuk tentang berbagai aspek kehidupan, baik agama, sosial dan lingkungan. Sampai anak menjadi dewasa dan berdiri sendiri.

Burgess dan Locke mengemukakan karakteristik keluaga. Menurut mereka terdapat 4 karakteristik yang terdapat pada semua keluarga yang berfungsi untuk membedakan keluarga dari kelompok-kelompok sosial lainnya:

1. Keluarga adalah susunan orang-orang yang disatukan oleh ikatan-ikatan perkawinan, darah atau adopsi.

2. Anggota-anggota keluarga ditandai dengan hidup bersama dibawah satu atap dan merupakan susunan satu rumah tangga.

3. Keluarga merupakan kesatuan dari orang-orang yang berinteraksi dan berkomunikasi yang menciptakan peranan-peranan sosial bagi si suami dan istri, ayah dan ibu, putra dan putri, saudara laki-laki dan perempuan.

4. Keluarga adalah pemelihara suatu kebudayaan bersama, yang diperoleh pada hakikatnya dari kebudayaan umum, tetapi dalam suatu masyarakat yang kompleks masing-masing keluarga mempunyai ciri-ciri yang berlainan dengan keluarga lainnya. Berbedanya kebudayaan dari setiap keluarga timbul melalui komunikasi anggota-anggota keluarga yang merupakan gabungan dari polapola tingkah laku individu ${ }^{12}$.

Keluarga dibentuk melalui pernikah mempunyai beberapa fungsi sekaligus fungsi tersebut menjadi tanggung jawab keluarga. Banyak fakta menjunjukkan

12 Ibid 
keberhasilan keluarga di dalam mendidikan anak-anaknya disebabkan oleh dilakukannya apa yang menjadi fungsi dari hubungan suami istri tersebut dalam rumah tangga. Menurut Oqburn, fungsi keluarga adalah kasih sayang, ekonomi, pendidikan, perlindungan, rekreasi, status keluarga, dan agama ${ }^{13}$.

Fungsi-fungsi keluarga ini membuat interaksi antar anggota keluarga eksis sepanjang waktu. Waktu terus berjalan dengan membawa konsekuensi perkembangan dan kemajuan. Keluarga dan masyarakat tidak lepas dari pengaruh-pengaruh tersebut, sehingga perubahan apa yang terjadi di masyaraka, berpengaruh pula di keluarga.

Agar seorang keluarga lebih efektif didalam mendidik kepribadian seorang anak, maka melakukan proses nuclear family ${ }^{14}$

\section{B. Penerapan di Lingkungan Masyarakat}

Manusia merupakan makhluk yang memiliki keinginan untuk menyatu dengan sesamanya serta alam lingkungan di sekitarnya. Dengan menggunakan pikiran, naluri, perasaan, keinginan dansebagainya manusia memberi reaksi dan melakukan interaksi dengan lingkungannya. Pola interaksi sosial dihasilkan oleh hubungan yang berkesinambungan dalam suatu masyarakat. Masyarakat bukanlah hanya sekedar suatu penjumlahan individu semata, melainkan suatu sistem yang dibentuk dari hubungan antar mereka, sehingga menampilkan suatu realita tertentu yang mempunyai ciri-cirinya sendiri. Masyarakat merupakan gejala (fenomena) sosial yang ada dalam kehidupan ini diseluruh dunia. Oleh karena itu masyarakat oleh sosiologi dijadikan sebagai objek kajian atau suatu hal yang dipelajari terus-menerus. Karena sifat dari masyarakat itu sangat kompleks, banyak para akhli yang menjelaskan masyarakat dari sudut pandang yang berbeda-beda.

${ }^{13}$ Abu Ahmadi, Sosiologi Pendidikan, (Surabaya: PT Bina Ilmu, 1982), h. 104

${ }^{14}$ Nasution, Sosiologi Pendidikan, (Jakarta: Bumi Aksara, 1999), h. 126 
208 | Belajea: Jurnal Pendidikan Islam, Vol. 2, No. 02, 2019

Ada beberapa ciri khas kehidupan masyarakat kolektif, yaitu: (1) pembagian kerja yang tetap antara berbagai macam sub-kesatuan atau golongan individu dalam kolektif untuk melaksanakan berbagai macam fungsi hidup; (2) ketergantungan individu kepada individu lain dalam kolektif sebagai akibat dari pembagian kerja; (3) kerjasama antar-individu yang disebabkan karena sifat ketergantungan; (4) komunikasi antar individu yang diperlukan guna melaksanakan kerjasama; (5) diskriminasi yang diadakan antara individu-individu warga kolektif dan individu-individu dari luar ${ }^{15}$.

Unsur-unsur dari masyarakat itu ada enam (6), yaitu: masyarakat, komunitas, kategori sosial, golongan sosial, kelompok, dan perkumpulan ${ }^{16}$. Menurut Soerjono Soekamto yang diktip oleh Gunawan, ada 4 (empat) unsur yang terdapat dalam masyarakat, yaitu: (1) adanya manusia yang hidup bersama, (dua atau lebih); (2) mereka bercampur untuk waktu yang cukup lama, yang menimbulkan sistem komunikasi dan tata cara pergaulan lainnya; (3) memiliki kesadaran sebagai satu kesatuan; dan (4) merupakan sistem kehidupan bersama yang menimbulkan kebudayaan ${ }^{17}$.

Kehidupan Kolektif dalam Alam Binatang, tidak hanya makhluk manusia saja, melainkan juga banyak jenis makhluk lain hidup bersama individu-individu sejenisnya dalam gabungan. Ada beberapa ciri khas kehidupan kolektif, yaitu: (1) pembagian kerja yang tetap antara berbagai macam sub-kesatuan atau golongan individu dalam kolektif untuk melaksanakan berbagai macam fungsi hidup; (2) ketergantungan individu kepada individu lain dalam kolektif sebagai akibat dari pembagian kerja; (3) kerjasama antar-individu yang disebabkan karena sifat ketergantungan; (4) komunikasi antar individu yang diperlukan guna

${ }^{15}$ Koentjaraningrat, Pengantar Ilmu Antropologi, (Jakarta: Aksara Baru, 1980), h. 149-152

${ }^{16} \mathrm{Ibid}$, h. 156

17 Gunawan, Sosiologi Pendidikan: Suatu Kajian Analisis Sosiologi Tentang Pelbagai Problem Pendidikan, (Jakarta: PT Rineka Cipta, 2010), cet, kedua, h. 4 
melaksanakan kerjasama; (5) diskriminasi yang diadakan antara individu-individu warga kolektif dan individu-individu dari luar ${ }^{18}$.

Mengenai azaz-azaz pergaulan antara makhluk dalam kehidupan alamiah itu, beberapa ahli filasafat seperti H.Spencer pernah menyatakan bahwa azaz egoisme atau azaz "mendahulukan kepentingan diri sendiri diatas kepentingan yang lain," mutlak perlu bagi jenis-jenis makhluk untuk dapat betahan dalam alam yang kejam. Sebaliknya, ada beberapa ahli filasafat lain yang menunjukan bahwa lawan azaz egoisme, yaitu azaz altruisme, atau azaz "hidup berbakti untuk kepntingan yang lain,” juga dapat membuat jenis makhluk itu menjadi sedemikian kuatnya sehingga dapat bertahan dalam proses seleksi alam yang kejam.

Walaupun demikian masih ada suatu perbedaan azasi yang sangat dasar antara kehidupan kolektif binatang dan kehidupan kolektif manusia, yaitu bahwa sistem pembagian kerja, aktivitas kerjasama, serta berkomunikasi dalam kehidupan kolektif binatang bersifat naluri, yaitu merupakan suatu kemampuan yang telah terencana oleh alam dan terkandung dalam gen jenis binatang yang bersangkutan, sedangkan pada manusia bukan bersifat naluri. Hal ini disebabkan karena lepas dari pengaruh ciri-ciri ras, baik Kaukasoid, Mongolid, Negroid atau lainnya, organisma manusia mengevolusi suatu otak yang khas. Otak mnusia telah mengembangkan suatu kemampuan yang biasanya disebut "akal". Akal manusia mampu untuk membayangkan dirinya serta peristiwa-peristiwa yang mungkin terjadi terhadap dirinya, sehingga dengan demikian manusia dapat mengadakan pilihan serta seleksi terhadap berbagai alternatif dalam tingkah lakunya untuk mencapai evektivitas yang optimal dalam mempertahankan hidupnya terhadap kekejaman alam sekelilingnya.

${ }^{18}$ Konentjaraningrat, op.cit, h. 149-152 
210 | Belajea: Jurnal Pendidikan Islam, Vol. 2, No. 02, 2019

Pendidikan haruslah membuka jiwa manusia terhadap alam jagat dan Penciptanya, terhadap kehidupan dan benda hidup, dan terhadap bangsa-bangsa dan kebudayaan-kebudayaan yang lain. Islam tidak mengenal fanatisme, perbedaan kulit atau sosial, sebab di dalam Islam tidak ada rasialisme, tidak ada perbedaan antara manusia kecuali karena taqwa dan iman. Firman Allah swt yang artinya: "Wahai manusia, Kami ciptakan kamu dari laki-laki dan perempuan dan Kami jadikan kamu berbangsa dan bersuku-suku supaya mengenal satu sama lain. Sesunggubnya yang paling mulia di antara kamu adalab yang paling bertaqwa."19

Jadi pendidikan Islam adalah pendidikan kemanusiaan yang berdiri di atas persaudaraan seiman (tidak ada beda antara orang Arab atau orang 'Ajam kecuali karena taqwa). Pendidikan Islam adalah pendidikan universal yang diperuntukkan kepada umat manusia seluruhnya ${ }^{20}$. Tidak heran apabila Ahmad Tafsir mengatakan bahwa sekolah adalah miniatur masyarakat atau masyarakat dalam bentuk mini. Jika orang ingin meneropong masyarakat teroponglah sekolahnya. Bila sekolah penuh disiplin, maka masyarakatnya tak jauh beda, dan jika sekolah penuh dengan penipuan, maka penipuan itu juga terjadi dalam masyarakat ${ }^{21}$. Lembaga pendidikan dalam kontek ini seakan menjadi cermin dari sebuah kehidupan masyarakat. Ketika sekolah sudah acuh dengan orang miskin, kaum difabel, maka dapat disimpulkan masyaraktnyapun lebih parah.

Akan tetapi pendidikan Islam menginginkan masyarakat menjadi kontrol terhap penyelenggaraan pendidikan, apakah yang dipraktikkan di sekolah masih sesuai dengan ajarang Islam, jiwa kemanusiaan, dan konsep Baldatun Thayyibatun Warabbun Ghafur. Pendidikan Islam memandang bahwa masyarakat muslim itu satu ikatan dan satu kehidupan. Ini didasarkan pada hadis Rasulullah yang artinya: "engkau melihat orang-orang mukmin dalam hal saling mencintai dan

${ }^{19}$ QS. Al-Hujurat: 13

${ }^{20}$ Hasan Langgulung, Pendidikan Islam dalam Abad ke 21, h. 176-179

${ }^{21}$ Ahmad Tafsir, Filsafat Pendidikan, (Bandung, Rosda Karya, 1992), Lihat juga Agus salim Dkk, Indonesia Belajarlah, (Yogyakarta, Tiara Wacana; 2007) 
menyayanginya seperti satu tubuh; jika salah satu anggotanya terserang penyakit maka selurub tubuh akan tidak dapat tidun dan merasa deman"22.

Hadits ini mengabarkan kepada sesama umat muslim untuk saling membantu. Implikasi edukatifnya mewajibkan masyarakan untuk membantu saudara seagama yang miskin agar bisa mengenyam pendidikan juga. Bukan sebaliknya, malah melecehka mereka dan memandang mereka sebelah mata. Disamping sabda Rasul, Allah berfirman di dalam Al-qur'an, yang artinya: “... dan janganlah sekali-kali kebencian(mu) kepada sesuatu kaum karena mereka menghalanghalangi kamu dari Masjidilharam, mendorongmu berbuat aniaya (kepada mereka). dan tolong-menolonglab kamu dalam (mengerjakan) kebajikan dan takwa, dan jangan tolongmenolong dalam berbuat dosa dan pelanggaran. dan bertakwalah kamu kepada Allah, Sesunggubnya Allah Amat berat sikesa-Nya."23

Berdasarkan ayat di atas, pendidikan Islam hendak mengenyampingkan rasa egois dan acuh terhadap kaum lemah. Pendidikan bukan hanya milik mereka yang kaya, yang ber IQ tinggi melainkan juga milik segenap manusia. Konsep pendidiakan Islam selanjutanya adalah tolong menolong antara sesama manusia. Mereka yang terpuruk pendidikan lantaran persoalan ekonomi harus diangkis bareng-bareng oleh masyarakat yang lebih mampu. Sesuai dengan ayat di atas pendidikan Islam hanya mengajarkan kebaikan kepada semua manusia tanpa memandang status sosial.

Konsep keterbukaan dan humanisasi dalam pendidikan Islam senada dengan nafas sosiologi profetik. Sosiologi profetik senapas dengan kecenderungan ilmu sosial kritis yang memberi pemihakan pada transformasi sosial dan pemberdayaan masyarakat. Transformasi dan humanisme teosentrisme yang mengangkat kembali martabat manusia. Dengan cara ini, manusia memusatkan perhatian pada Tuhan, tetapi tujuannya untuk kepentingan

22 Shahih Bukharim Vol.IV, p. 37, al-Mathba'ah al-Ustsmaniyah, Mesir, $1351 \mathrm{H}$.

${ }^{23}$ Q.S al-Maidah: 2 
212 | Belajea: Jurnal Pendidikan Islam, Vol. 2, No. 02, 2019

manusia ${ }^{24}$. Humanisasi diperlukan karena masyaraka sedang berada dalam tiga keadaan akut, yaitu dehumanisasi (obyektivasi teknologis, ekonomis, budaya, dan negara), agresivitas (agresivitas kolektif dan kriminalitas), dan loneliness (privatisasi, individualisasi) ${ }^{25}$.

Kebiasaan hidup sendiri, kapitalisme pendidikan, kriminalitas sudah menjangkit lembaga pendidikan. Banyak lembaga pendidikan yang membuka jurasan baru dan menaikkan biaya pendidikan hanya menuruti kepentingan pasar dan ekonomi. Pendidikan Islam sangat membenci praktik seperti itu, masyarakat diharapkan mampu menjadi kontrol yang kuat terhadap lembaga pendidikan. Dalam proses penyadaran para praktisi pendidikan, masyarakat dapat membuka ruang dialekatika dengan mereka. Selain itu, jika terbuka oknum pendidikan sudah melupakan ajaran Islan, kemanusiaan maka harus disangsi secara moral sebagai cambukan agar tidak diulangi dan teruskan.

\section{Penerapan di Lingkungan Sekolah}

Sekolah adalah sebuah lembaga yang dirancang untuk pengajaran siswa (atau "murid") di bawah pengawasan guru. Ada juga sekolah non-pemerintah, yang disebut sekolah swasta. Sekolah swasta mungkin untuk anak-anak dengan kebutuhan khusus ketika pemerintah tidak bisa memberi sekolah khusus bagi mereka; keagamaan, seperti sekolah Islam, sekolah Kristen, hawzas, yeshivas dan lain-lain, atau sekolah yang memiliki standar pendidikan yang lebih tinggi atau berusaha untuk mengembangkan prestasi pribadi lainnya. Sekolah untuk orang dewasa meliputi lembaga-lembaga pelatihan perusahaan dan pendidikan dan

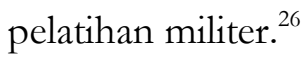

230

${ }^{24}$ Kuntowijoyo, Paradigma Islam: Interpretasi Untuk. Aksi, (Bandugn: Mizan, 1991), h. 228-

${ }^{25}$ Kuntowijoyo, Muslim Tanpa Masjid: Esai-Esai Agama, Budaya, dan Politik dalam Bingkai Strukturalisme Transsindental, (Bandung: Mizan, 2001), h. 366-369

${ }^{26}$ http://id.wikipedia.org/wiki/Sekolah, jam, 08:00 tanggal 15 Mei 2017 
Dengan demikian, sekolah merupakan sarana yang secara sengaja dirancang untuk melaksanakan pendidikan. Karena kamajuan zaman, maka keluarga tidak mungkin lagi memenuhi seluruh kebutuhan dan aspirasi anak terhadap iptek. Semakin maju suatu masyarakat, semakin penting peranan sekolah dalam mempersiapkan generasi muda sebelum masuk dalam proses pembangunan masyarakat itu. Sekolah merupakan tempat untuk mendapatkan ilmu pengetahuan dan pembinaan kepribadian. Di sekolah seorang anak mencoba untuk melakukan dialog dengan guru, berinteraksi dengan sahabatsahabatnya dan melakukan proses menghargai dan mentaati aturan.

Dengan kemajuan zaman juga dalam menyajikan materi pembelajaran seharusnya dengan menggunakan "media audio visual yaitu media yang mempunyai unsur suara dan gambar. Dalam media audio visual ini bisa berupa film suara, film bingkai suara" ${ }^{27}$ agar materi pembelajaran bisa langsung dipahami dan diingat oleh peserta didik.

Kebudayaan sekolah adalah semua kehidupan di sekolah serta normanorma yang berlaku di dalamnya ${ }^{28}$. Kebudayaan sekolah merupakan bagian kecil dari kebudayaan di masyarakat, akan tetapi ada perbedaan yang khas diantara keduanya. Kebudayaan di sekolah lebih menekankan kepada proses pembelajaran dan evaluasi hasil belajar. Selain norma-norma yang diperlakukan di sekolah, ada kebuadayaan lain seperti kenaikan kelas, upacara-upacara, dan upacar bendera.

Lembaga pendidikan yang melaksanakan pembinaan pendidikan dan pengajaran dengan sengaja, teratur dan terencana adalah Sekolah. Guru-guru yang melaksanakan tugas pembinaan, pendidikan dan pengajaran tersebut adalah

27 Fadila Fadila and Eka Yanuarti, 'Pelayanan Sosial Dan Keagamaan Dengan Menggunakan Media Audio Visual Dalam Meningkatkan WPKNS ABH Di Lembaga Permasyarakatan Kelas II A Curup', ISLAMIC COUNSELING: Jurnal Bimbingan Konseling Islam, 2019 <https://doi.org/10.29240/jbk.v3i1.798>.

${ }^{28}$ S. Nasution, Sosiologi Pendidikan, (Jakarta: Bumi Aksara, 2009), cet. IV, h. 64 
214 | Belajea: Jurnal Pendidikan Islam, Vol. 2, No. 02, 2019

orang-orang yang telah dibekali dengan pengetahuan tentang anak didik, dan memiliki kemampuan untuk melaksanakan tugas kependidikan. ${ }^{29}$

Tugas kependidikan disini tidak hanya tugas yang berbentuk pengetahuan semata tetapi tugas kependidikan disini adalah mengenai kecerdasan spiritual peserta didik. Kecerdasan spiritual yaitu kecerdasan yang berkenaan dengan hati dan kepedulian antar sesama manusia, makhluk lain, dan alam sekitar berdasarkan keyakinan akan adanya Tuhan Yang Maha Esa. ${ }^{30}$

Didalam GBPP PAI di sekolah umum, dijelaskan bahwa pendidikan agama Islam adalah usaha sadar dalam menyiapkan siswa dalam meyakini, memahami, menghayati dan mengamalkan agama Islam melalui kegiatan bimbingan, pengajaran, dan atau latihan dalam memperhatikan tuntutan untuk menghormati agama lain dalam hubungan kerukunan antarumat beragama dalam masyarakat untuk mewujudkan persatuan Nasional ${ }^{31}$.

Usaha pembelajaran pendidikan agama Islam di sekolah diharapkan agar mampu membentuk kesalehan pribadi dan sekaligus kesalehan sosial sehingga pendidikan agama diharapkan jangan sampai: (1) menimbulkan semangat fanatisme; (2) menumbuhkan intoleran dikalangan peserta didik dan masyarakat indonesia; dan (3) memperlemah kerukunan hidup beragama serta persatuan dan kesatuan nasional (Mentri Agama RI, 1996). Wal hasil, pendidikan agama islam di harapkan mampu menciptakan Ukhuwah Islamiyah dalam arti luas, yaitu ukbuwah fi al-ubudiyah, ukhuwah fi al-insaniyah, ukhuwah fi al-wathoniyah wa al-nasab, ukhuwah fi din al-islam ${ }^{32}$.

${ }^{29}$ Zakiah Darajat, Ilmu Pendidikan Islam, Jakarta: Bumi Aksara, 2010), h. 77

30 Atika Fitriani and Eka Yanuarti, 'Upaya Guru Pendidikan Agama Islam Dalam Menumbuhkan Kecerdasan Spiritual Siswa', BELAJEA: Jurnal Pendidikan Islam, 2019 <https://doi.org/10.29240/belajea.v3i2.527>.

${ }^{31}$ Muhaimin, Paradikma Pendidikan Islam, (Bandung: Rosdakarya, 2003), h. 76

${ }^{32}$ Ibid, h. 82 


\section{Analisis Tujuan Aktualisasi Diri}

\section{Pembentukan Insan Shaleh}

Yang dimaksud dengan insan shaleh adalah manusia yang mendekati kesempurnaan, dengan kata lain pengembangan manusia yang menyembah dan bertaqwa kepada Allah sebagaimana dalam firmanNya: “..Tidaklah Aku ciptakan jin dan manusia kecuali agar mereka menyembah kepadaKu.."33, manusia yang penuh keimanan dan taqwa, berhubungan dengan Allah memelihara dan menghadap kepadaNya dalam segala perbuatan yang dikerjakan dan segala tingkah laku yang dilakukannya, segala pikiran yang tergores di hatinya dan segala perasaan yang berdetak di jantungnya.

Yang harus diperhatikan di sini ialah bahwa makna menyembah sebagaimana ayat di atas tidak dimaksudkan shalat sebagai upacara ibadah yang kita pahami. Menyembah dalam pengertian luas adalah mengembangkan sifat Tuhan yang diberikan kepada manusia ${ }^{34}$. Inilah manusia yang mengikuti jejak langkah Rasul saw. dalam pikiran dan perbuatannya.

Di antara akhlak insan yang shaleh dalam Islam adalah harga diri, prikemanusiaan, kesucian, kasih sayang, kecintaan, kekuatan jasmani dan rohani, menguasai diri, dinamis, dan tanggung jawab. Ia memerintahkan yang ma.ruf dan melarang yang mungkar. Ia juga bersifat benar, jujur, ikhlas, memiliki rasa keindahan dan memiliki rasa keseimbangan pada kepribadiannya; jasad, akal, dan roh semuanya tumbuh dan pertumbuhannya terpadu, juga memakmurkan dunia dan mengeluarkan hasilnya ${ }^{35}$.

\section{Pembentukan Masyarakat Shaleh}

Masyarakat shaleh adalah masyarakat yang percaya bahwa ia mempunyai risalah (message) untuk umat manusia, yaitu risalah keadilan, kebenaran, dan

${ }^{33}$ QS. Adz-Dzariat: 56

${ }^{34}$ Hasan Langgulung, Kreativitas dan Pendidikan Islam, (Jakarta: Pustaka Al-Husna, 1991), Cet. 1, h. 296-297

35 Hasan Langgulung, Pendidikan Islam dalam Abad 21, Op.Cit., h. 169-170 
216 | Belajea: Jurnal Pendidikan Islam, Vol. 2, No. 02, 2019

kebaikan, suatu risalah yang akan kekal selamanya, tidak terpengaruh faktor waktu dan tempat. Untuk memperoleh masyarakat shaleh tentu saja dimulai dari insan pribadi dan keluarga yang shaleh. Dalam hal ini umat Islam hendaknya berusaha sekuat tenaga memikul tanggung jawab yang diamanahkan kepadanya kapan dan dimana saja. Tugas pendidikan Islam adalah menolong masyarakat mencapai maksud tersebut. Selanjutnya, Hasan Langgulung mengklasifikasikan tugas pendidikan Islam pada masyarakat berdasarkan tantangan-tantangan yang dihadapi oleh dunia Islam adalah pada hal-hal berikut:

a. Menolong masyarakat membangun hubungan-hubungan sosial yang serasi, setia kawan, kerja sama, interdependen, dan seimbang sesuai dengan firman Allah: "Sesunggubnya orang-orang mukmin itu bersaudara.."36

b. Mengukuhkan hubungan di kalangan kaum muslim dan menguatkan kesetiakawanannya melalui penyatuan pemikiran, sikap, dan nilai-nilai. Ini semua bertujuan menciptakan kesatuan Islam.

c. Mengukuhkan identitas budaya Islam. Ini dapat dicapai dengan pembentukan kelompok-kelompok terpelajar, para pemikir dan kaum ilmuan yang: a) Bersemangat Islam, sadar dan melaksanakan ajarannya, prihatin dengan peninggalan peradaban Islam, disamping bangga dan bersedia membelanya sehingga karya-karyanya mempunyai corak Islam sejati. b) Menguasai sains dan teknologi modern dan bersifat terbuka terhadap budaya lain. c) Bersifat produktif, terutama dalam hal mengarang, membuat karya inovatif, dapat menyelaraskan potensi-potensi yang ada, dan membimbing orang lain. d) Bebas dari ketergantungan kepada orang atau budaya lain, dan tidak memiliki sifat taklid buta ${ }^{37}$.

Dalam buku bertajuk 'How Communities Build Stronger Schools', Anne Wescott dan Jean L. Konzal menggambarkan pola hubungan keluarga, sekolah,

${ }^{36}$ Q.S. At- Taubah: 10

${ }^{37}$ Hasan Langulung, Op. Cit., h. 172-175 
dan masyarakat dalam tiga paradigma yang mengalami perubahan dan perkembangan. Ketiga paradigma hubungan tripusat pendidikan dapat dijelaskan sebagai berikut:

a. Paradigma lama

Orang tua dalam keluarga, warga sekolah, dan warga masyarakat memiliki hubungan sesuai dengan kepentingan masing-masing dalam urusan pendidikan. Dalam paradigma lama ini, hubungan tripusat pendidikan ini berlangsung sebagai satuan pranata sosial yang berdiri sendiri dan berada dalam posisi yang terpisah-pisah.

Guru dan warga sekolah dalam paradigma lama ini pada umumnya masih berkutat pada pertanyaan, "Apa yang orang tua, warga masyarakat, dan organisasi masyarakat dapat lakukan untuk kami (sekolah)?" Jawaban yang ingin mereka dapatkan daripihak orangtua dan masyarakat hanya berupa uang transpor atau baju seragam atau honorarium kelebihan jam mengajar. Jadi, guru dan warga sekolah masih terfokus pada dukungan finansial dari keluarga dan masyarakat. Dengan demikian, keluarga dan warga masyarakat pun sudah merasa telah memberikan peran utamanya, jika ia telah memberikan dukungan finansial kepada sekolah. Masalah proses belajar mengajar, urusan belajar anak di rumah, pembinaan moral peserta didik, seluruhnya telah diserahkan sepenuhnya kepada sekolah. Orang tua dan masyarakat hanya ingin tahu bahwa anaknya lulus dengan nilai yang tinggi. Kalau kemudian ada anak yang perilakunya tidak baik, atau tidak dapat mencapai standar kelulusan, orangtua dan masyarakat akan segera mengembalikan tanggungjawab semua itu kepada sekolah.

b. Paradigma Transisional

Dalam paradigma transisional, hubungan antara sekolah dan orangtua telah berkembang sebagai hubungan kerja sama yang sudah interaktif. Pola hubungandalam paradigma transisional ini memiliki beberapa karakteristik yang 
218 | Belajea: Jurnal Pendidikan Islam, Vol. 2, No. 02, 2019

agak berbeda dengan karakteristik paradigma lama, antara lain adalah: (1) menitikberatkan pada penguasaan akademik dan perkembangan individual siswa, (2) kurang birokratis, lebih manusiawi, dantelah terjadi hubungan dua arah, (3) proaktif, (4) lebih inklusif, (5) perbedaan kultural dan sosial sudah memperoleh perhatian, (6) kerja sama dengan orangtua sudah terbentuk secara terbatas,

Beberapa karakteristik paradigma lama sudah mulai mengalami perubahan, meski belum secara total. Sebagai contoh, perhatian orangtua dan masyarakat terhadap anak-anak dari keluarga tidak mampu sudah mulai tumbuh, misalnya dengan adanya program beasiswa atau program subsidi silang. Dengan demikian, lembaga pendidikan sekolah sudah tidak terlalu birokratis lagi. Sekolah sudah menjadilebih inklusif. Dalam konteks paradigma transisional, sekolah dan keluarga menanyakan kepada diri dan masayakat "bagaimana orangtua, warga masyarakat, organisasi social dapat membantu kita untuk melaksanakan tugas secara lebih baik".

c. Paradigma Baru

Karatkteristik hubungan tripusat pendidikan dalam paradigma baru ini telah benar-benar berubah secara total, yang berbeda dengan paradigma sebelumnya, yakni: (1) menitikberatkan perhatian pada siswa secara keseluruhan, baik aspek akademis maupun perkembangan individualnya, (2) tidak ada batas hubungan antar keluarga, sekolah, dan masyarakat, (3) terjadi budaya menemukan, belajar, melindungi, dan membimbing; guru dan orangtua melaksanakan penelitian tindakan bersama-sama, (4) keikutsertaan secara personal, (5) tidak hirarkis, sepenuhnya inklusif, setiap orang merasa dirangkul, (6) terdapat kerjasama antara orang tua dan masyarakat, (7) orangtua dan warga masyarakat sebagai patner, (8) menemukan manfaat bersama sebagai tujuan.

Dalam paradigma baru ini, semua orang (orangtua dalam keluarga, kepala sekolah dan guru di sekolah, serta warga masyarakat) secara bersama-sama 
mengajukan pertanyaan tentang "apa yang kita dapat kerjakan bersama untuk mendidik semua anak dengan baik". Dalam hal ini, pertanyaan tentang bagaimana cara mendidik peserta didik itu tidak lagi hanya menjadi tanggung jawab profesional para pendidik dan kepala sekolah dan tenaga administrasi di sekolah saja, melainkan telah melibatkan peran serta secara sinergis dari semua stakeholder pendidikan. Dengan demikian, paradigma baru tentang hubungan tripusat pendidikan ini telah memandang lembaga pendidikan sekolah sebagai milik bersama. Dengan kata lain, tidak ada lagi "single fighter" dalam pengelolaan dan penyelenggaraan pendidikan di sekolah.

\section{Penutup}

Disamping peningkatan kontribusi dalam perannya masing masing, keluarga, sekolah, dan masyarakat terhadap perkembangan peserta didik, diprasyaratkan pula keserasian kontribusi ini, serta kerjasama yang erat dan harmonis antar ketiga pusat pendidikan anak tersebut. Berbagai upaya harus dilakukan, program pendidikan dari setiap unsur sumber pendidikan yaitu keluarga, sekolah dan masyarakat diharapkan dapat saling mendukung dan memperkuat antara satu dengan yang lainnya.

Misalnya, dilingkungan keluarga telah diupayakan berbagai hal (perbaikan gizi, permainan edukatif, penanaman ahlak baik dan sebagainya) yang menjadi landasan pengembangan selanjutnya di sekola dan masyarakat. Dilingkungan sekolah diupayakan berbagai hal yang lebih mendekatkan sekolah dengan orang tua siswa (seperti membuat organisasi orang tua dan guru). Selanjutnya sekolah juga mengupayakan agar programnya berkaitan erat dengan masyarakat sekitar.

Dengan masing masing peran yang dilakukan dengan baik oleh keluarga, sekolah maupun masyarakat dalam pendidikan, yang saling memperkuat dan 
220 | Belajea: Jurnal Pendidikan Islam, Vol. 2, No. 02, 2019

saling melengkapi antara ketiga pusat itu, akan memberi peluang besar mewujudkan sumber daya manusia terdidik yang bermutu dan insan shaleh.

\section{Bibliogapy}

Assegaf, Abd. Rachman. 2004, Membangun Format Pendidikan Islam di Era Globalisasi., dalam Imam Machali dan Musthofa (Ed.), Pendidikan Islam dan Tantangan Globalisasi, Yogyakarta: Ar-Ruzz Media.

Ahmadi,Abu, 2004, Sosiologi Pendidikan, Jakarta: Rineka Cipta.

An-Nawawi, Adurrahman, 1989, Prinsip-Prinsip dan Metode Pendidikan Islam:

Dalam Keluarga, Di Sekolah dan Di Masyarakat, Bandung: cv. Dipenogoro.

Arifin, HM. 1996, Filsafat Pendidiken Islam. Bumi Aksara. Jakarta, Cet V.

Bernadib, Imam, 1983, Pemikiaran Tentang Pendidikan Baru. Yogyakarta: Andi Offset.

Bukhari, Shahih, Vol.IV, p. 37, al-Mathba'ah al-Ustsmaniyah, Mesir, $1351 \mathrm{H}$. Usaha Nasional.

Darajat, Zakiah. 2010. Ilmu Pendidikan Islam. Jakarta: Bumi Aksara, 2010.

Fadila, Fadila, and Eka Yanuarti, 'Pelayanan Sosial Dan Keagamaan Dengan Menggunakan Media Audio Visual Dalam Meningkatkan WPKNS ABH Di Lembaga Permasyarakatan Kelas II A Curup', ISLAMIC COUNSELING: Jurnal Bimbingan Konseling Islam, 2019 <https://doi.org/10.29240/jbk.v3i1.798>

Fahri, Musthafa, 1977, Kesehatan Jiwa Dalam Keluarga, sekolah, dan Masyarakat, Jakarta: Bulan Bintang.

Fitriani, Atika, and Eka Yanuarti, 'Upaya Guru Pendidikan Agama Islam Dalam Menumbuhkan Kecerdasan Spiritual Siswa', BELAJEA: Jurnal Pendidikan Islam, 2019 <https://doi.org/10.29240/belajea.v3i2.527>

Gunawan, H., 2010, Sosiologi Pendidikan: Suatu Kajian Analisis Sosiologi Tentang Pelbagai Problem Pendidikan, Jakarta: PT RINEKA CIPTA.

Koesoema A, Doni, 2007, Pendidikan Karakter: Strategi Mendidik Anak di Zaman Global, Jakarta: Grasindo.

Koentjaraningrat, 1980, Pengantar Ilmu Antropologi, Jakarta: Aksara Baru.

Kuntowijoyo, 2001, Muslim Tanpa Masjid: Esai-Esai Agama, Budaya, dan Politike dalam Bingkai Strukturalisme Transsindental, Bandung: Mizan.

Langgulung, Hasan, 1995, Beberapa Pemikiran tentang Pendidikan Islam, Bandung: Al-Ma.arif.

Husna Baru. 2003, Pendidikan Islam dalam Abad ke 21, Jakarta: Pustaka Al- 
Husna.

Maragustam, 2010, Mencetak Pembelajaran Menjadi Insan Paripurna. Yogyakarta: Nuha litera, Cet. Pertama.

Muhaimin, 2003, Paradikma Pendidikan Islam, Bandung: Rosdakarya.

Nasution, S.,2009. Sosiologi Pendidikan,Jakarta: Bumi Aksara.

Nizar, Samsul, 2009, Sejarah Pendidikan Islam menelusuri jejak sejarah pendidikan era

Rasulullah sampai Indonesia. Yogyakarta: Kencana Prenada Media Group. Cet ke-3.

Soekanro, Soerjono, 1992, Sosiologi Keluarga: Tantangan Ikhwal Keluarga Remaja dan Anak, Jakarta: PT Rineka Cipta.

Supriyanto, Moh. Padil Triyo, 2007, Sosiologi Pendidikan,Malang: UIN Malang Pers.

Salim, Agus Dkk, 2007, Indonesia Belajarlah Yogyakarta, Tiara Wacana.

Tafsir, Ahmad, 1992, Filsafat Pendidikan, Bandung, Rosda Karya.

Tim Dosen IKIP Malang, 2003, Pengantar Dasar-Dasar Pendidikan, (Surabaya, Kuntowijoyo, 1991, Paradigma Islam: Interpretasi Untuk Aksi, Bandung: Mizan.

Shihab, M. Quraish, 1994, Prinsip-prinsip Pengembangan Sumber Daya Manusia dalam Pandangan Islam., Majalah Triwulan Mimbar Ilmiah, Universitas Islam Djakarta, Tahun IV No. 13, Januari

Yanuarti, Eka, 'Pendidikan Islam Dalam Perspektif Filsafat Idealisme', BELAJEA: Jurnal Pendidikan Islam, 2016 <https://doi.org/10.29240/BJPI.V1I2.108>

Yanuarti, Eka, 'Pola Asuh Islami Orang Tua Dalam Mencegah Timbulnya Perilaku LGBT Sejak Usia Dini', Cendekia: Jurnal Kependidikan Dan Kemasyarakatan, 2019 <https://doi.org/10.21154/cendekia.v17i1.1337> 
222 | Belajea: Jurnal Pendidikan Islam, Vol. 2, No. 02, 2019 